\title{
Conceptual Difficulties Encountered by Science Teacher Candidates in Static Electricity
}

\author{
M. Said Doğru* \\ * Kastamonu University, Araç Rafet Vergili Vocational School, Kastamonu, Turkey, (ORCID: 0002-9516-1442), msaid.dogru@yahoo.com
}

(First received 11 April 2021 and in final form 12 December 2021)

(DOI: 10.31590/ejosat.913290)

ATIF/REFERENCE: Doğru, M. (2021). Conceptual difficulties encountered by Science teacher candidates in static electricity. European Journal of Science and Technology, (31), 957-967.

\begin{abstract}
Static electricity is an introduction to electricity in all high school and university Physics textbooks. Definitions of static electricity phenomena are not clear, including in higher education. This research was conducted to determine the fundamental difficulties that teacher candidates encounter in explaining static electricity. They conducted electrostatic experiments focusing on different electricity in the Introduction's context to Physics Laboratory Lesson. At the end of the class, the data were collected through the reports they wrote. The qualitative content analysis method was used in the analysis of the data. The convenient sample comprises 400 science teacher candidates (270 girls and 130 boys). The analysis showed that teacher candidates had significant difficulties in conceptualizing the microscopic processes - with inductive loading - that explain this phenomenon. Some observe that the different roles played by electrons in conductors and insulators pose difficulties for science teacher applicants. The findings emphasized microscopic models during macroscopic experimental processes. This may help teacher candidates to understand the role of electrons in conductors and insulators and the different mechanisms involved in electrification.
\end{abstract}

Keywords: Conceptual challenges, teacher candidates, content analysis, static electricity

\section{Fen Bilgisi Öğretmen Adaylarının Statik Elektrik Konusu İle İlgili Karşılaştıkları Kavramsal Zorluklar}

$\ddot{O} z$

Statik elektrik, tüm lise ve üniversite Fizik ders kitaplarında elektriğe giriş bölümüdür. Statik elektrik olaylarının tanımları, yüksek öğrenimde de dahil olmak üzere açık değildir. Bu araştırma, öğretmen adaylarının statik elektriği açıklamada karşılaştıkları başlıca zorlukları belirlemek için yapılmıştır. Fizik Laboratuvarına Giriş Dersi bağlamında farklı elektrik türlerine odaklanan elektrostatik deneyler yapmışlardır. Dersin sonunda veriler yazdıkları raporlar aracılığıyla toplanmıştır. Verilerin analizinde nitel içerik analiz yöntemi kullanılmıştır. Elverişli olan örneklem 400 fen bilgisi öğretmeni adayından (270 kız ve 130 erkek) oluşmaktadır. Analiz, öğretmen adaylarının bu olayı açıklayan mikroskobik süreçleri - daha spesifik olarak, tümevarımla yükleme - kavramsallaştırmada önemli zorluklar yaşadığını göstermiştir. Elektronların iletkenlerde ve yalıtkanlarda oynadığı farklı roller, fen bilgisi öğretmen adayları için zorluklar oluşturduğu görülmüştür. Bulgular, makroskopik deneysel süreçler sırasında mikroskobik modellere vurgu yapmıştır. Bu durum, öğretmen adaylarının iletkenler ve yalıtkanlarda elektronların rolünü ve elektirklenmede yer alan farklı mekanizmaları anlamalarına yardımcı olabilir.

Anahtar Kelimeler: kavramsal zorluklar, öğretmen adayları, içerik analizi, statik elektrik.

\footnotetext{
* Corresponding Author: msaid.dogru@yahoo.com
} 


\section{Introduction}

Electrical events are an important part of the science curriculum at all levels of education, from primary school to university. In elementary school, students are taught the concepts of charges and electrical circuits to prepare for later learning and understanding more complex concepts and procedures related to electromagnetic phenomena. Understanding the fundamentals of electricity to grasp more abstract issues such as electric potential, electric field, Gauss's law, and capacitance- for example, Coulomb's law, the distinction between conductors and insulators, transfer and conservation of charge- propagation of electromagnetic waves (Maloney et al., 2001). Electricity, just like mechanics, is a field of Physics that students find much more difficult to get than other fields. To grasp electrical concepts and ideas, they must be able to relate macroscopic phenomena to microscopic procedures.

Studies on student misconceptions in electrostatics have focused on electric fields and the forces applied by electric fields to charges (Eylon \& Ganiel, 1990; Furio \& Guisasla, 1998; Thong \& Gunstone, 2008; Savelsbergh, Jong \& FergusonHessler, 2011; Planinic, 2006). The findings of these studies have shown that most students do not clearly understand the electric field concept and suffer from several misunderstandings. For example, students have difficulties with the representation of electric field lines. According to Taşkın (2021), students believe that the line of force will be the true trajectory of the moving charge. A simple interpretation of this answer could be that a single line of force contains only one piece of information: the direction of the force applied to the load. Students are guided to visualize the concept of field lines based on a relatively familiar trajectory. Another source of confusion between trajectory and force lines could be a belief that force lines are true conduction paths for electrical effects. Besides, Törnkvist et al. (1993) and Planinic (2006) stated that students think electric field lines can both cross each other and form sharp boundaries. I understand field lines as isolated entities rather than a set of curves representing the electric field vector as a property of space. This explains the misunderstanding of electric force and electric field (field lines) as linear vectors, regardless of the type of charge. Other misunderstandings include "field lines can begin and end anywhere" and "there are a few field lines" (Maloney et al., 2001; Singh, 2006). Research into students' understanding of simple electric direct current (DC) circuits has shown that many students find it very difficult to apply qualitative reasoning to explain the observed phenomenon. Some argue these difficulties stem from failing to construct models of microscopic processes that produce this phenomenon (Guisasola, 2014).

Since electricity is used in everyday situations, it makes sense that both students and adults suffer from many misunderstandings when trying to understand and explain the phenomenon related to them (Ersoy \& Dilber, 2014). Although the textbooks started their discussions on electricity with the concept of electric charge, the students did not clearly understand the load as a concept (Eylon \& Ganiel, 1990; Pardhan \& Bano, 2001; Thacker et al., 1999).

The students' most typical misconceptions are that 'a neutral object has no charge' (Calilot \& Xuan, 1993; Thacker et al., 1999; Dori \& Belcher, 2005) and explains the concept of electric charge that 'a charged object contains only electrons or protons'. '(Siegel \& Lee, 2001). Regarding the concept of static electricity, they believe that 'friction is the (only) cause of static electricity (Calilot \& Xuan, 1993; Siegel \& Lee, 2001).

Guruswamy et al. (1997) showed that students and teacher candidates faced many difficulties in charge transfer in static electricity.

Guruswamy et al. (1997) showed that students and teacher candidates faced many difficulties in charge transfer in static electricity. Some examples may include: 'No charge transfer between two metal objects with the same sign', 'Transfer between oppositely charged metal objects occurs until one object is neutral', 'No transfer between a charged metal. Object and a neutral metal object 'and' The charges on two metal objects remain the same after touch regardless of the signs of the initial charges'. Calilot \& Xuan (1993) discussed the fact that adults accepted similar misconceptions. Besides, Hermita et al. (2017) created and implemented a test to diagnose teacher candidates' misconceptions about static electricity. The results included ideas such as "Electrostatic objects cannot attract neutral objects", "A neutral object is an object without an electric charge" and "The magnitude of the pull between two charged objects depends on the size of the charge." Park's research identified students' previous ideas about the electrostatic induction phenomenon (Park, 2001). At the beginning of the interview, most of both middle school and college students can predict the motion of the leaves inside the electroscope in a conductor state, but not in an insulator state. While examining their answers, the researchers found that most students could make scientifically acceptable explanations for the phenomenon of induction regarding conductors, but not with insulators (polarization). Students could describe the induction of conductors because of electron transfer within the conductor but had difficulty explaining the corresponding procedure (polarization) inside insulators.

Regarding the Science Education curriculum in Europa, science has been included in the last two years of primary school. Primary school comprises 1-6. Grades (6-12-year-old students). In particular, during the fifth year, 11-year-old students are introduced to "basic" electrical ideas and phenomena such as atomic structure so that they can understand positive and negative electric objects, three types of charges, and related phenomena such as static, curly hair, and how an electroscope works. The subject at hand is how to ensure successful science education in primary school, and there is an important contribution to the science education of teacher candidates. Although several research projects on electricity have been conducted in science education (Guisasola, 2014), only a few have focused on the difficulties that teacher candidates encounter in the microscopic processes of static electricity. Some studies on electrostatics have suggested that teacher candidates have alternative concepts related to basic concepts in electrostatics and that teacher candidates have difficulty learning concepts related to electrostatics (Atasoy, 2013, Başer \& Geban, 2007; Simayi, 2004); Park, Kim \& Lee, 2001). Some common alternative concepts have been identified in the studies on electrostatics. The most remarkable of these alternative concepts is the misrepresentation of load distributions in conductive and insulating objects, that insulating objects cannot be loaded or that they can transmit loads such as conductors everywhere (Şekercioğlu, 2011). In the results obtained from some studies, participants can act on their positive load (Ciğdemtekin, 2007; Gülçiçek, 2016) and it was determined that there would be a uniform load on the loaded objects (Başer, 
2003; Demirci and Çirkinoglu, 2004; Ciğdemtekin, 2007; Güneş, 2013; Gulçicek, 2016).

With the findings in the literature, this is the issue addressed in this research that contributes to the design of teaching strategies focusing on microscopic procedures, not just macroscopic phenomena.

\section{Method}

\subsection{Purpose of the Research}

This study aimed to reveal the conceptual difficulties of science teacher candidates about static electricity. In our research, he formed part of a larger General Physics Laboratory Lesson (GFLL) comprising five confirmatory laboratory studies, one of which was electrostatics. Regarding this research, the following questions were asked:

a) To what extent could the teacher candidates create scientific explanations about static electricity?

b) What are the conceptual difficulties that classroom teacher candidates encounter regarding the mechanisms by which static electricity is generated?

\subsection{Research Method}

The field study was carried out in the Department of Mathematics and Science Education of a state university in the Western Black Sea Region in the fall term of 2017-2018.

This research was prepared qualitatively for a crosssectional design. The data were collected at once through a questionnaire. Thus, information about certain existing beliefs will be better provided (Gay et al., 2012). The study aimed to determine the conceptual difficulties faced by primary school teacher candidates regarding static electricity. In this sense, the study tried to reveal the relevant microscopic processes that teacher candidates had difficulty explaining. The tool used here is an open-ended questionnaire in which teacher candidates can express their explanations about the phenomenon of static electricity in writing. All participants answered the same question set in the questionnaire. Both qualitative and quantitative methods were used to analyze the data.

\subsection{Population and Sample/ Study Group/ Participants}

The sample comprised 400 first-grade teacher candidates: 270 women and 130 men. The easy sampling method was chosen to choose the participants because of their easy access. However, in the current courses, the data were collected reliably as they already had to submit the written report to pass the course (GFLL).

Regarding their scientific education and science, most of the teacher candidates accepted to the department have turned to Science. According to the curriculum of the Ministry of National Education, subjects including the structure of the atom, static electricity, conductors, and insulators are covered in the science and technology course in the eighth grade of secondary school. The teacher candidates attended the General Physics Lesson (GFL) at the same time as GFLL. However, when they took part in static electricity laboratory experiments, the relevant theories were not yet taught through GFL. Their responses were therefore taken independently of GFL or derived from laboratory practice or previously gained knowledge.

\subsection{Data Collection Tools/ Procedures}

The teacher candidates taking part in the GFLL were divided into 16 teams of 25 people and worked. GFLL comprised five three-hour laboratory practice sessions, standing on their own once a week: 1) taking measurements, 2) mechanics, 3) optics, 4) static electricity and 5) Ohm's law. Participants were provided with materials to prepare for each laboratory exercise. Related theory and some examples are also included in this section. For example, it included examples of charging materials by contact with static electricity. The experiments examined are confirmatory in that teacher candidates have to test the relatively simple hypotheses they have prepared. While conducting these exercises, they were required to describe the experimental material: Tools, devices, and daily materials. They were informed of how long each task would take, so they could set their own pace and encouraged their colleagues to take an active role. The teaching sequence, including three static electricity experiments, is explained in detail in Appendix I.

Regarding the research data, 400 separate written reports containing open-ended questions and which are the final outputs of the GFLL were collected. The questionnaire on static electricity was presented to students as part of the general written report. It comprises six open-ended questions that teacher candidates can express their views freely about static electricity: The first four questions are friction and contact loading; the last two questions are about induction loading. Five of the six questions are based on the function of the electroscope in terms of types of charges. The last question is focused on polarization. Since the study is also a part of the final evaluations, all participants answered the questions (response rate $100 \%$ ).

\subsection{Data Analysis}

Both qualitative and quantitative methods are used. Conceptual content analysis was used to code the answers of the teacher candidates. For methodological reasons regarding reliability, the data has been pre-coded. Subsequently, inductive categories were created by the first three author-coders (Cohen's kappa 0.8), which was sufficient according to Mayring (2000). Here, the content unit is the answers that the participants add to their written reports. Quantitative analysis steps (e.g., percentages), called descriptive statistics, were followed to quantify the findings and provide a clearer case for conceptual challenges (Gay et al., 2012). .05 alpha level was used for all statistical tests.

\subsection{Findings}

Content analysis of the teacher candidates' written reports showed that many could give scientifically accepted descriptions of friction and contact loading, but had difficulties explaining electrostatic induction. Especially: Regarding electrical loading by friction and touch, most of the teacher candidates made scientifically accepted explanations. Many teacher candidates have described friction electricity as the transition of electrons from one substance to another, assuming that electrons are looser from one substance to another. Regarding touch or contact, teacher candidates were able to easily identify the mechanism by which the neutral object will be charged since electrons will pass to the neutral object when a neutral object is touched by a charged object (e.g., negatively charged). The neutral object, therefore, receives a negative charge, and the initially charged object becomes less negative. A few teacher candidates $(12 \%)$ 
revealed their difficulties in understanding the structure of the because of proton or electron transfer (Table 1). atom by describing friction and contact electrical charging

Table 1. Response percentages of teacher candidates on friction and contact loading

\section{Scientifically accepted answers}

$\% 87$

In Table 2, coded examples of scientifically accepted and not accepted responses are presented.

\section{Proton or electron transfer}

$\% 13$

Table 2. Examples of teacher candidates 'views on electrification through friction and contact

\begin{tabular}{lc}
\hline $\begin{array}{l}\text { Thematic } \\
\text { category }\end{array}$ & \multicolumn{1}{c}{ Scientifically accepted answers } \\
\hline $\begin{array}{l}\text { Electrification } \\
\text { by friction }\end{array}$ & $\begin{array}{l}\text { During friction, looser electrons (e.g. Electrons of } \\
\text { one object) are transferred to another object. As a } \\
\text { result, one object is loaded positively and the other } \\
\text { object is loaded negatively. We don't know which } \\
\text { one is for each pair, but it depends on the electrons. }\end{array}$
\end{tabular}

\section{Electrification A negatively charged object gives some of its} by touch electrons to the electroscope. That is why it opens. If the rod is positively charged, electrons pass from the electroscope to the bar. As a result, the plates of the electroscope are positively charged and push each other.

\section{Non-accepted answers}

Friction causes electrons or protons to be transferred from one object to another.
The glass bar gives its positive load to electrical and causes the plates to open.
Table 2 presents the opinions of the teacher candidates on the differences between conductors and insulators. Most of the candidates made precise statements regarding the fact that the tip of the glass rod is not electrified, since glass is an insulator and electrons cannot move from one side of the material to the other. Most of the participants explained that the load from the friction is in its original position. A few candidates (23\%) made a different statement: the leaves of the electroscope did not open since there was no electric charge when all the charge was transmitted during the previous experiment. Regarding touching the other side of the metallic cylinder, namely the part with the sticker, most of the participants could explain why the electroscope leaves were opened by describing the free movement of electrons in the metal. Most of the teacher candidates attributed this feature to the metal being the cylinder. Few of them $(12 \%)$ were observed to fail their experiments, possibly because of the discharge of the electrical charge of the cylinder. The teacher candidates could explain this situation because of the lack of electrical charge of the cylinder. Although there are close comments to the glass rod explanations here, their interpretations from different places stand out.

\section{Percentage of teacher candidates' answers}

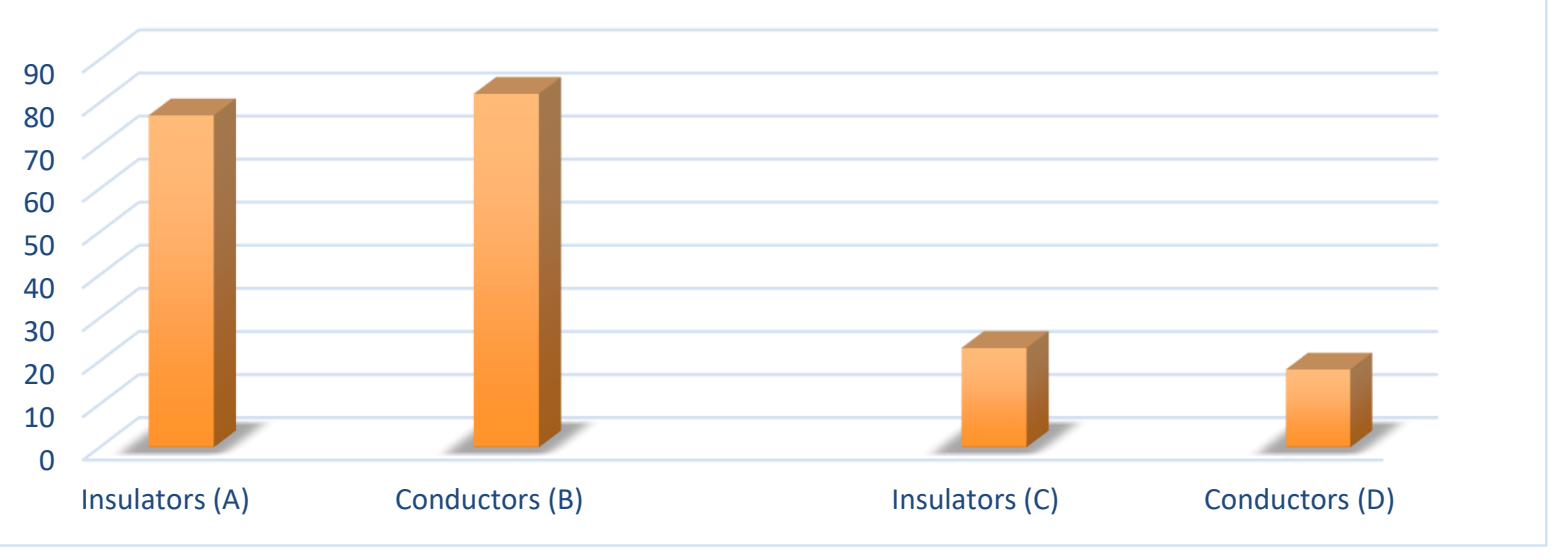


Table 3 presents examples of teacher candidates' views on insulators and conductors. About the induction charging of conductors, $68 \%$ of the teacher candidates made complete explanations. Most of the candidates had difficulty explaining why the electroscope turned on when brought near the charged glass rod. Specifically, $32 \%$ of the participants were observed to believe that the electric charge of the glass rod is transferred by air to the metal disc (Figure 3), and the metal disc as a conductor allows the electric charge to move to the plates. The greatest evidence for this is the statements about the electroscope charging with the same electrical charge. Here, the teacher candidates attributed the charge of the electroscope plates not to the motion of the electrons inside the electroscope, but to a charge resulting from transferring electric charge from the rod to the metal disk. They stated that even from a distance, the charge of the rod will be transferred to the metal disc of the electroscope. Regarding the induction (dielectric polarization) charging of insulators, only $10 \%$ of the natural procedure discussed successfully responded. Most of the teacher candidates (90\%) could not explain the mechanism by which the molecules in the styrofoam of the glass rod are polarized because of static electricity. Specifically, the attraction between the rod and the styrofoam pendulum (Figure 3 ) is explained:

Table 3. Examples of teacher candidates 'views on conductors and insulators

$\begin{array}{lll}\text { Thematic category } & \text { Scientifically accepted answers } & \text { Non-accepted answers }\end{array}$

Conductive

Because electrons move freely in

conductors, there is a load at the other end

Because of the previous touch with the electroscope, the cylinder is out of charge.

of the metallic cylinder, and the

electroscope is therefore opened.

\section{Insulators}

\section{Because electrons do not move inside} insulters, there is no electrical charge at the other end of the glass bar.
At the other end of the glass bar, there is no electric charge left. Because it is all over in the previous experiment.

\section{According to Table 3;}

The state of attraction between a charged and neutral object: $38 \%$ of the teacher candidates stated that the charged glass rod attracts the styrofoam ball, which is electrically neutral, so two charged objects are not needed. The teacher candidates did not explain in any way the displacement of electrons in the same molecule in polarization. Here, they used an explanatory framework that the electric force between electrical and nonelectrical objects can be transferred. They could not explain how the electrostatic properties of the neutral knob of the pendulum are formed.

The state of attraction between oppositely charged objects: $24 \%$ of the teacher candidates claimed that the attraction between the stick and the styrofoam ball was because of the two objects having opposite charges, but they could not explain how the ball was electrified in the opposite direction.

The state of attraction between objects with opposite charges resulting from electron transfer from one object to another: $18 \%$ of the teacher candidates claimed that the charged glass rod provides electrons to the styrofoam ball from a certain distance, the electric charge "jumped" from the rod to the styrofoam ball in the air. This electron transfer causes the rod to lose all its electrons and ultimately to be positively charged, while the styrofoam pendulum is negatively charged. Here, the teacher candidates used an alternative explanatory framework based on the "construction" of two oppositely charged objects: the positive rod and the negative styrofoam ball.

The result of the glass rod's contact with the styrofoam pendulum. $11 \%$ of the teacher candidates thought the hammer was caused by the loaded rod and the pendulum ball. They argued that during the contact between two objects, the electrically charged rod gives electrons to the pendulum ball, keeping the ball negative and the rod positively charged. Therefore, they explained that the attraction between the styrofoam ball and the glass rod is because of the loading of the ball with an electric charge opposite to the load on the rod. The candidates did not realize that the two objects attract each other from a distance, they are pushed if they touch each other. 


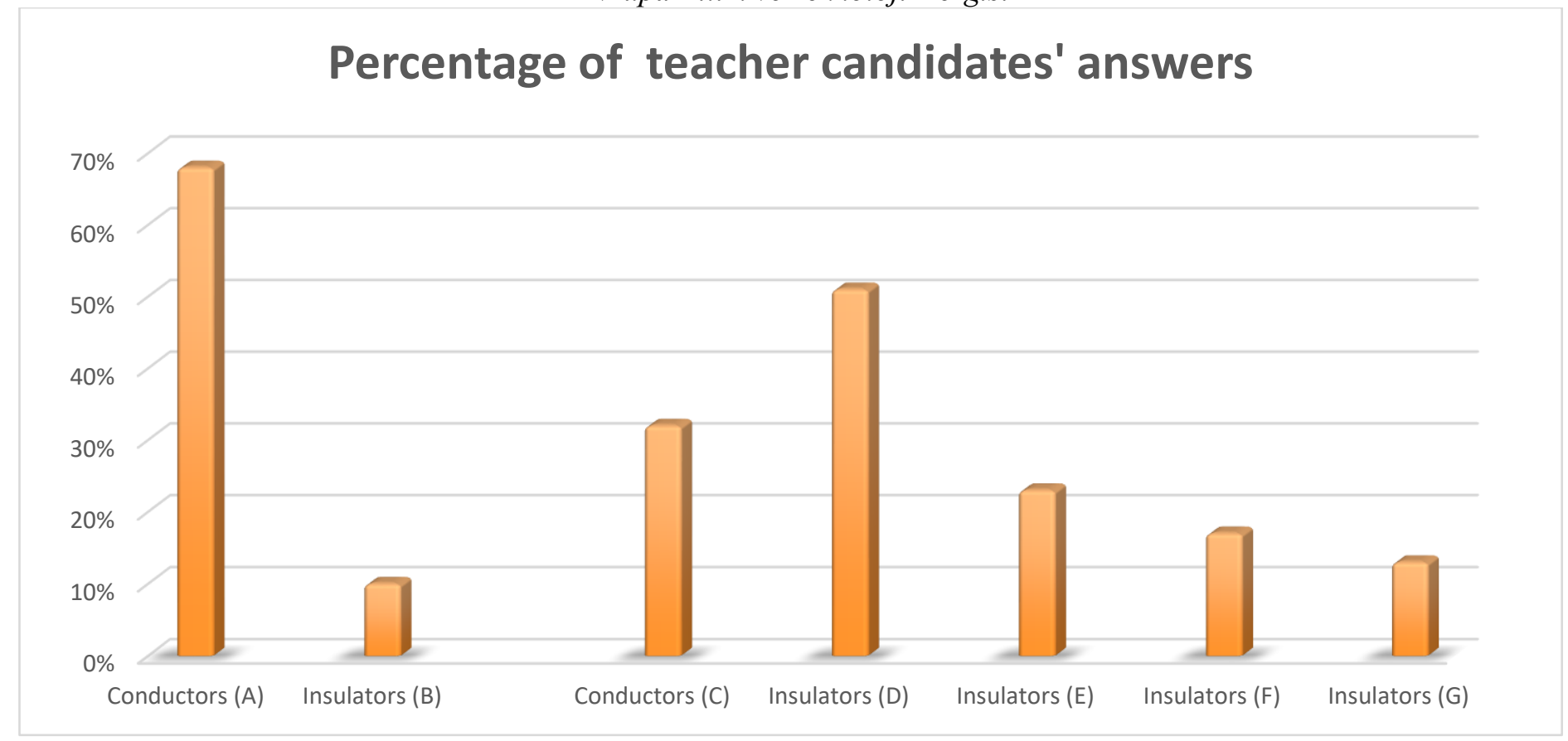

A-B: scientifically accepted answers. C: The electric charge of the charged object is transferred through the air to the neutral conductor. D: Attraction without explanation. E: Attraction due to the oppositely charged object. F: The charged object offers electrons at a distance to the neutral object. G: Attraction because of the contact between the object.

\section{Figure 2. Teacher Candidates' views on electrostatic induction- polarization}

In Table 4, examples of the responses of 51 teacher candidates, coded as scientifically accepted or not, about inductive electrification are presented. The answers that were not scientifically accepted were classified according to their content (C, D, E, F, G) and shown in Figure 2.

To determine whether there is a statistically significant difference between the percentages of teacher candidates who gave correct and incorrect answers, respectively, a single-sample t-test was conducted. When the answers about friction and contact electricity were examined, it was found that there was a significant difference between the scores of scientifically accepted responders (89\%) and those who did not (11\%) ( $\mathrm{t}(399)$ $=20.032, \mathrm{p}<.001)$. These results (Table 4$)$ show that most of the teacher candidates could give scientifically accepted explanations about friction and electrification by touch.

Although many teacher candidates have scientifically accepted opinions by testing the difference between conductors and insulators, we find that they have difficulty understanding the different roles electrons play in conductors and insulators with a statistically significant percentage. When the responses of the teacher candidates about induction electrification were examined, it was found that a statistically significant percentage of them attributed electron induction to electron transfer via air from the metal cylinder to the electroscope (Table 5).

A comparison was made between scientifically accepted answers and answers given to different categories in the case of charging with dielectric polarization (Table 6). A statistical difference was found between the teacher candidates who gave scientifically accepted answers $(22 \%)$ and those who could not make a meaningful explanation (54\%) $(\mathrm{t}(399)=22.721, \mathrm{p}$ $<.001)$. These findings show that most of the teacher candidates have deficiencies in explaining dielectric polarization. Such a hypothesis is supported by the comparison of the three different categories that the remaining $(24 \%)$ teacher candidates encountered; attraction between objects with opposite charges $(21 \%)$, electron transfer through the air $(17 \%)$, and attraction (16\%) because of electrification by touch.

However, there was no significant difference between those who gave scientifically accepted answers $(22 \%)$ and those who attributed dielectric polarization to objects with opposite charges $(21 \%)$. Similarly, the percentage of accepted responses was not found to be significantly different when compared to responses linking polarization to airborne electron transfer (Table 7). Finally, there is no significant difference between the percentage of scientifically accepted answers and those that link polarization to gravity because of electrification by touch; $(t$ $(399)=5.926, p=0.47)$. Although some differences were not statistically significant, the results provided powerful evidence that teacher candidates encountered difficulties in explaining static electricity and, in particular, induction and dielectric polarization. 
Teacher candidates' answers

Scientifically accepted answers

\section{Conductive}

Styrofoam electrons cannot move as freely as conductors do. To illustrate, when the positively charged rod is approached by the styrofoam ball, the atoms in the Styrofoam are directed as if the electrons were trying to approach the positive object.

\section{Insulators}

When the negatively charged glass rod is brought to the electroscope, it pulls the electrons from the metals. The plates are negatively charged and they are opening.

Attraction without
$\begin{gathered}\text { The glass rod is charged, and that is why it } \\ \text { explanation (Non-accepted }\end{gathered}$
attracts the ball.

answers)

The attraction between oppositely charged objects

(Non-accepted answers) Electrons' transfer through the air (Non-accepted answers)

\section{Attraction as a result of} contact charging (Nonaccepted answers)

That doesn't pull each other because the rod and ball don't load against each other.

Electrons pass through the air to the ball in the rod. Therefore, the two objects attract each other because of contrasting loads.
One object is positive and the other is negative because electrons pass through the air from the rod to the electroscope or versa. They pull each other.

The rod and ball are loaded against each other without touching each other and do not attract each other.

Table 5. Statistics of teacher candidates 'answers about friction, touch and induction electrification

\begin{tabular}{|c|c|c|c|}
\hline Teacher candidates' answers & Scientifically accepted (\%) & Non-accepted (\%) t-test & One-sample t-test \\
\hline Friction and contact electricity & 89 & 11 & $\begin{array}{c}\mathrm{t}(399)=20.032, \mathrm{p}< \\
.001\end{array}$ \\
\hline Insulators & 77 & 23 & $\begin{array}{c}\mathrm{t}(399)=7,204, \mathrm{p}< \\
.001\end{array}$ \\
\hline Conductors & 93 & 7 & $\begin{array}{c}\mathrm{t}(399)=23,143, \mathrm{p}< \\
.001\end{array}$ \\
\hline Induction & 68 & 32 & $\begin{array}{c}\mathrm{t}(199)=5.411, \mathrm{p}< \\
.001\end{array}$ \\
\hline
\end{tabular}

Table 6. Statistics of teacher candidate responses on dielectric polarization

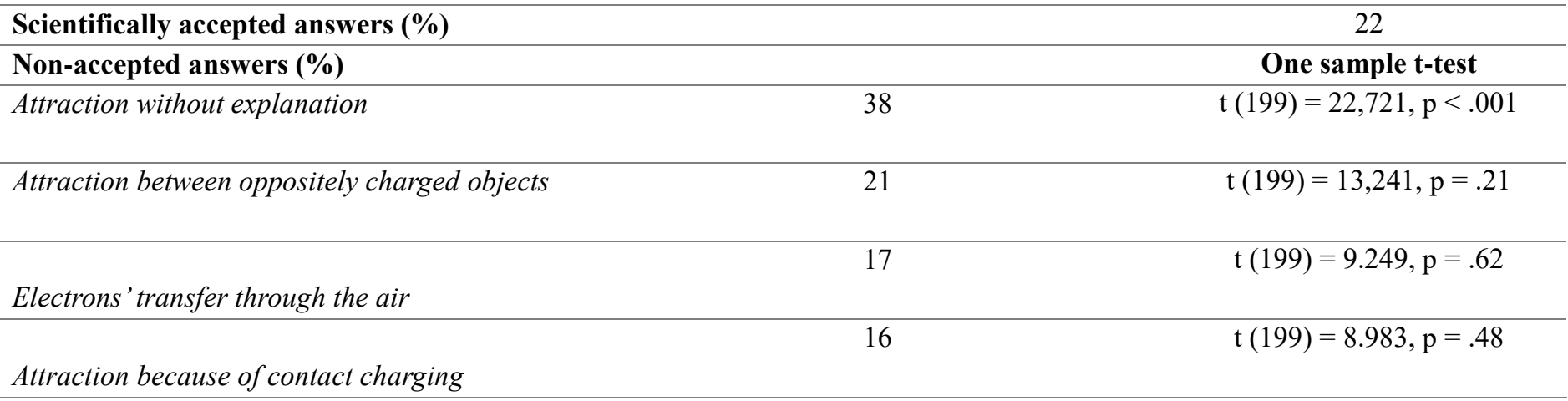




\begin{tabular}{|c|c|c|c|}
\hline $\begin{array}{l}\text { Teacher candidates' accepted } \\
\text { answers }(\%)\end{array}$ & $\begin{array}{c}\text { Scientifically accepted answers } \\
(\%) \\
\text { Female }\end{array}$ & $\begin{array}{c}\text { Scientifically accepted answers } \\
(\%) \\
\text { Male }\end{array}$ & Double sample t-test \\
\hline Friction and contact electricity & 192 & 197 & $\begin{array}{c}\mathrm{t}(398)=1.016, \mathrm{p}< \\
.342\end{array}$ \\
\hline Insulators & 175 & 183 & $\begin{array}{c}\mathrm{t}(398)=1.245, \mathrm{p}< \\
.291\end{array}$ \\
\hline Conductors & 187 & 188 & $\begin{array}{c}\mathrm{t}(398)=0.152, \mathrm{p}< \\
.795\end{array}$ \\
\hline Induction & 160 & 170 & $\begin{array}{c}\mathrm{t}(398)=1.423, \mathrm{p}< \\
.211\end{array}$ \\
\hline Polarization & 90 & 92 & $\begin{array}{c}\mathrm{t}(398)=0.198, \mathrm{p}< \\
.785\end{array}$ \\
\hline
\end{tabular}

To determine whether there is a statistically significant difference according to gender, a two-sample t-test was conducted. The results (Table 7) show that there is no statistically significant difference between the answers of male and teacher candidates.

\section{Discussion}

This study aimed to address to what extent science teacher candidates can construct scientifically accepted views about processes related to static electricity after a GFLL and all the negativities detected. The teacher candidates answered an openended questionnaire comprising six questions about three different electrifications.

Based on the content analysis of the teacher candidates' written reports, it was revealed that most of the participants could make scientifically accepted explanations for electrification by friction and touch. It has been observed that the conceptual difficulties are mainly related to the induction and polarization processes.

Regarding electrification by friction and touch, most of the teacher candidates could explain the relevant microscopic processes and stated that charging progresses towards electron transfer. This result revealed that the participants perceived electrification as a process that occurs only through friction. Explanations are supporting this finding in the literature (Başer \& Geban, 2007; Y1ldı, 2011; Stefanidou et al., 2019). However, the results reveal a few teacher candidates encountered difficulties in explaining electrification by friction and touch, mistakenly seeing the transfer of protons or electrons from one object to another as a reason for charging. It was also observed that these teacher candidates had difficulty associating the atomic structure in electrification with touch and friction. These findings are consistent with the results of the research reported in the literature (Tezcan \& Salmaz, 2005; Sarıkaya, 2007; Stefanidou and et al., 2019). It was also observed that the teacher candidates could not attribute their knowledge about the atom to their explanations about electrification by friction and touch. Here, although the teacher candidates knew atoms cannot be transmitted by touch, it was revealed that they could not understand the state of proton transfer between objects. They could see that the glass rod, metal cylinder, wood, and the fabric did not change during the experiments.

e-ISSN: 2148-2683
The findings of this study showed that the difficulties experienced by teacher candidates were primarily related to induction/polarization processes. In particular, these difficulties can be expressed as teacher candidates' electrostatic induction, a process of free electrons moving from one part of an object to another because of another charged object (induction in conductors), or an electron redistribution within the atom or molecules closest to the outer surface of the object (polarization in insulators). Most of the teacher candidates were found to encounter difficulties when they were asked to explain the meaning of electrostatic properties to a neutral object by induction. In the literature, a similar situation was encountered in the studies that participants had difficulty in understanding that a neutral object can carry a charge and therefore interpreting electrostatics (Calilot \& Xuan, 1993; Thacker et al., 1999). Students who define electrons as the gravitational force when passing to other objects have also appeared in the studies of Başer and Geban (2007). Here it appears to be related to the poor understanding of the structure of conductors and insulators and the role played by free electrons in them. The reason for this situation can be explained by the teacher candidates' avoidance of expressing their opinions about induction and polarization mechanisms. Because they did not distinguish between the role of mobile free electrons in conductors and the role of electrons attached to less mobile atoms in insulators.

These findings make more sense, especially when it is considered that the participants in this study lacked the experience of teaching atomic theory, electrostatics, conductors, insulators, etc. This may be evidence that students contribute little to their focus on macroscopic phenomena and their understanding of microscopic procedures. It is also similar to the conclusion presented in the relevant literature (Voutsina \& Ravanis, 2011; Dederberg, 2012; Cheng, 2015; Stefanidou et al., 2019) and introduces the electrical curriculum with basic electrical phenomena (electrification by friction, contact, and induction) and microscopic methods to improve students' understanding It is suggested that they should focus on explanatory models.

When related studies are examined, it is stated that adults and secondary school and university students have great difficulty in understanding and explaining static electricity phenomena (Calilot \& Xuan, 1993; Eylon \& Ganiel, 1990; Guruswamy et al., 1997; Hermita et al., 2017; Siegel \& Lee., 


\section{European Journal of Science and Technology}

2001; Stefanidou et al., 2019; Thacker et al., 1999). This version has been revealed through research on DC electric circuits, electric shocks, electric fields, and other electrostatic issues; here - unlike other fields of Physics where processes, such as mechanics, can be directly visualized - everything observed can be as an indirect view of some.

The most important contribution of this research is to identify the conceptual challenges related to static electricity by focusing on three types of electrification. Such an approach revealed that teacher candidates were associated with the difficulties they experienced in connecting atomic structure to the phenomenon of static electricity.

Such findings are very important in addressing teacher candidates' understanding of science teaching in middle school, especially for good teaching and methods, and in identifying any confusion at the microscopic level.

The findings of this study prove that teacher candidates have difficulties in understanding both the microscopic procedures related to induction, dielectric polarization, and the differences between conductors and insulators. According to the results got are the difficulties associated with the different roles that electrons play in insulators and conductors. Therefore, the research is likely to show the need for a deeper analysis of microscopic procedures involved in electrostatics. Based on the findings of this study, further research may contribute significantly to teacher candidates' views on the role of conductors and insulators in electrostatics and electromagnetic phenomena.

It is proposed to establish macro-micro relationships based on electrostatic experiments supported by theories and models of production mechanisms in static electricity. It is important to include microscopic models in the electrical curriculum in schools and universities, as they help students understand the relationship between macroscopic phenomena and microscopiclevel patterns. Besides, inquiry-based teaching methods are recommended in which teacher candidates can actively take part in developing scientifically accepted explanations. Students will not only do experiments but also learn how to test their hypotheses and create models that attempt to explain static electricity phenomena. By comparing their models with sample software (eg Phet Colorado), they can progressively develop scientific explanations.

\section{Conclusion}

There are two purposes in this study: (1) To examine to what extent teacher candidates can construct scientific explanations about static electricity. (2) Identifying the conceptual difficulties that teacher candidates face when they have to explain the basic phenomena of static electricity: Electrification and induction by friction and touch. After the teacher candidates completed the GFLL, they submitted a written report in which they should express their views on the three types of electrification by answering six open-ended questions.

The results reveal that teacher candidates have difficulty in conceptualizing microscopic procedures that occur during electrification. Although the challenges are mainly related to charging through induction and dielectric polarization, the research has also revealed that they also encounter some difficulties with electrification by friction and touch. At the heart of such difficulties lies the lack of understanding of the atomic structure and hence the microscopic procedures that occur during induction. In particular, it turned out that the teacher candidates' responses found it very difficult to explain a poor understanding of the role played by each of the electrons in the three types of electrification, as well as the difference in the role of electrons between conductors and insulators.

Therefore, the most important contribution of this study is that although the findings are limited to the sample, the teacher candidates have difficulties with all three electrifications, which shows that there is a poor understanding of the atomic structure and a weak relationship between atomic structure and their knowledge about electrification. As this research shows, teacher candidates still have great difficulty explaining microscopic procedures related to static electricity phenomena, even though they have been included in the science curriculum at all educational levels from primary education to higher education. For this reason, it is important to increase the knowledge of teacher candidates, as this would help them gain sufficient knowledge. We can develop a more positive understanding of future students of these issues by helping them to develop their knowledge.

As a result, some alternative considerations are proposed, such as the use of inquiry-based teaching, in which microscopic models are integrated into macroscopic procedures and experiments to overcome the challenges expressed here. Further research in this area could shed light on the development of teaching-learning sequences that consider microscopic procedures related to electrical and other derivative issues.

Research findings are limited to the sample. Thus, research on conceptual challenges related to static electricity and the role of electrons can be repeated or studied with different methods to increase the reliability of the findings.

\section{References}

Atasoy, Ş. (2013). Effect of writing-to-learn strategy on undergraduates' conceptual understanding of electrostatics. The Asia Pacific Education Researcher, 22 (4), 593-602.

Başer, M., Geban, Ö. (2007). Effect of instruction based on conceptual change activities on students' understanding of static electricity concepts. Research in Science \& Technological Education, 25 (2), 243-267.

Caillot, M., \& Xuan, A. N. (1993). Adults' misconceptions in electricity. In The Proceedings of the Third International Seminar on Misconceptions and Educational Strategies in Science and Mathematics. NY: Ithaca.

Cheng, M. F., \& Lin, J. L. (2015). Investigating the relationship between students' views of scientific models and their development of models. International Journal of Science Education, 37(15), 2453-2475.

Çiğdemtekin, B. (2007). Fizik eğitiminde elektrostatik konusu ile ilgili kavram yanılgılarının giderilmesine yönelik bir karikatüristik yaklaşım (Yayımlanmamış yüksek lisans tezi). Gazi Üniversitesi, Ankara-Türkiye

Demirci, N. \& Çirkinoğlu, A. (2004). Öğrencilerin elektrik ve manyetizma konularında sahip oldukları ön bilgi ve kavram yanılgılarının belirlenmesi. Türk Fen Eğitimi Dergisi, 1(2), $116-138$ 
Dori, Y. J., \& Belcher, J. (2005). How does technology-enabled active learning affect undergraduate students' understanding of electromagnetism concepts?. The Journal of The Learning Sciences, 14(2), 243-279.

Ersoy, F. N., \& Dilber, R. (2014). Comparison of two different techniques on students' understandings of static electric concepts. International Journal of Innovation And Learning, 16(1), 67-80.

Eylon, B. S., \& Ganiel, U. (1990). Macro-micro relationships: The missing link between electrostatics and electrodynamics in students' reasoning. International Journal of Science Education, 12(1), 79-94. https://doi.org/10.1080/0950069900120107.

Furio, C., \& Guisasola, J. (1998). Difficulties in learning the concept of electric field. Science Education, 82(4), 511-526.

Guisasola, J. (2014). Teaching and learning electricity: The relations between macroscopic level observations and microscopic level theories. In International handbook of research in history, philosophy and science teaching. NY: Springer

Guruswamy, C., Somars, M. D., \& Hussey, R. G. (1997). References students' understanding of the transfer of charge between conductors. Physics Education, 32(2), 91-96.

Gülçiçek, N. (2016). Fen bilgisi öğretmen adaylarının elektrostatik konusunda teknolojik pedagojik alan bilgileri (Yayınlanmamış doktora tezi). Gazi Üniversitesi, AnkaraTürkiye.

Güneş, B. (2013). Fizikte Kavram yanılgıları. Ankara: Palme Yayınları.

Hermita, N., Suhandi, A., Syaodih, E., Samsudin, A., Isjoni, Johan, H., Rosa, F., Setyaningsih, R., Sapriadil \& Safitri, D. (2017). Constructing and implementing a four tier test about static electricity to diagnose pre-service elementary school teacher' misconceptions. Journal of Physics, 895(1), 012167.

Maloney, D. P., O’Kuma, T. L., Hieggelke, C. J., \& Van Heuvelen, A. (2001). Surveying students' conceptual knowledge of electricity and magnetism. American Journal of Physics, 69(S1), S12-S23.

Park, J. (2001). Analysis of students' processes of confirmation and falsification of their prior ideas about electrostatics. International Journal of Science Education, 23(12), 12191236.

Park, J., Kim, I., Kim, M., \& Lee, M. (2001). Analysis of students' processes of confirmation and falsification of their prior ideas about electrostatics. International Journal of Science Education, 23(12), 1219-1236.

Pardhan, H. ve Bano, Y. (2001). Fen bilgisi öğretmenlerinin doğrudan akımlarla ilgili alternatif kavramları. International Journal of Science Education, 23 (3), 301-318.

Planinic, M. (2006). Assessment of difficulties of some conceptual areas from electricity and magnetism using the
Conceptual Survey of Electricity and Magnetism. American Journal of Physics, 74(12), 1143-1148.

Sarıkaya, M. (2007). Prospective teachers' misconceptions about the atomic structure in the context of electrification by friction and an activity to remedy them. International Education Journal, 8(1), 40-63.

Savelsbergh, E. R., de Jong, T., \& Ferguson-Hessler, M. G. (2011). Choosing the right solution approach: The crucial role of situational knowledge in electricity and magnetism. Physical review special topics-Physics education research, 7(1), 010103.

Sederberg, D. (2012). Middle school students' mental models of magnets and magnetism (Unpublished doctoral dissertation). Purdue University, Indiana.

Siegel, M. A., \& Lee, J. A. (2001). "But Electricity Isn't Static": science discussion, ldentification of learning issues, and use of resources in a problem-based learning education course. ERIC Clearinghouse.

Simayi, A. N. (2014). The use of contextually appropriate analogies to teach direct current electric circuit concepts to isiXhosa speaking learners (Doctoral dissertation). Nelson Mandela Metropolitan University, South Africa.

Singh, C. (2006). Student understanding of symmetry and Gauss's law of electricity. American journal of physics, 74(10), 923-936

Stefanidou, C. G., Tsalapati, K. D., Ferentinou, A. M., \& Skordoulis, C. D. (2019). Conceptual Difficulties Pre-Service Primary Teachers Have with Static Electricity. Journal of Baltic Science Education, 18(2), 300.

Taşkın, T. (2021). Examination of prospective teachers' knowledge about capacitors and electric field lines. Research in Science \& Technological Education, 1-18.

Tezcan, H., ve Salmaz, Ç. (2005). Atomun yapısının kavratılmasında ve yanlış kavramaların giderilmesinde bütünleştirici ve geleneksel öğretim yöntemlerinin etkileri. Gazi Eğitim Fakültesi Dergisi, 25(1), 41-54.

Thacker, B. A., Ganiel, U., \& Boys, D. (1999). Macroscopic phenomena and microscopic processes: Student understanding of transients in direct current electric circuits. American Journal of Physics, 67(S1), 25-31.

Thong, W. M., \& Gunstone, R. (2008). Some student conceptions of electromagnetic induction. Research in Science Education, 38(1), 31-44.

Törnkvist, S., Pettersson, K. A., \& Transtr.mer, G. (1993). Confusion by representation: On student's comprehension of the electric field concept. American Journal of physics, 61(4), 335-338.

Voutsina, L., \& Ravanis, K. (2011). History of physics and conceptual constructions: The case of magnetism. Themes in Science and Technology Education, 4(1), 1-20.

Yıldız, F. (2011). Ilköğretim 7. sinıf ögrencilerinin elektrostatik konusuyla ilgili kavram yanılgılarının belirlenmesi 


\section{European Journal of Science and Technology}

(Yayımlanmamış yüksek lisans tezi). Balıkesir Üniversitesi Fen Bilimleri Enstitüsü, Balıkesir.

\section{APPENDIX 1}

The laboratory experiment examined in this study is related to static electricity.

Experiment A: Electrification by friction and contact. They are materials used in an arranged glass bar, a cylinder of metal, an electroscope, and a piece of wool.

Step 1: Students are asked to rub one end of the glass bar and touch the metal disk of the electroscope with the loaded rod.

Step 2: After the electroscope is neutralized, Students are asked to touch the metal disc of the electroscope with the part of the glass bar that is rubbed with wool.
Step 3: Students are asked to rub the metal cylinder with a woolen cloth and then touch the metal disc of the electroscope.

Step 4: After the electroscope is neutralized, Students are asked to touch the metal disc of the electroscope with the other end of the glass cylinder.

Experiment B: Electrification by Induction. They are materials used in an arranged pendulum, a glass bar, and an electroscope.

Step 1: Students are asked to electrify the glass bar with fractions and zoom in on the metal disc of the electroscope. Students are asked to rub the glass rod and zoom in on the pendulum.

Step 2: Students are asked to rub a glass bar with a woolen cloth and zoom in on the pendulum. 